\section{A FINGER-GUARD}

WIJTJAM 3. MANNING, M.D.

Aredfal ofliecer, Governenent l'rinting oflice

WASIIINGTON, D) (.

This protective device I lave found very practical and usefui in all cases of contusions received at the ends of fingers and toes, as well as after amputations of these members. Particularly will the guard be indicated at these points named where cientricial tissue bas been deposited or is being deposited during the healing process. The grunce will be found usef'ul in this class of injuries received hy medhanies and workjngmen who are obligerl to contimue at their work for economic rensons while the fingers are still "very tender." All blows or contucts to the injured memiser, it will be noticed, are recoived on the metallie bronstwork or conical point, and the force of any jar and impact is thus carried down and received on the boly of the finger or the healthy, normal tissue, and the shock

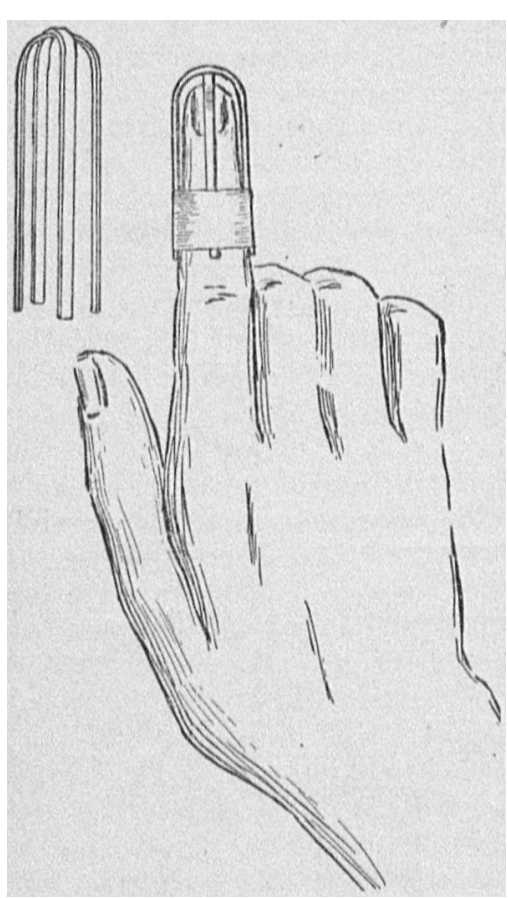

Finger-(iun red. to the aflected part is, conserpuently, greatly lessened and better distributer than if rereiver ilirectly on the primary injury.

At tinsmiths may be secured strips of tin or zine, ubout $1 / 16$ or $1 / 8$ ind wide and approximntely 4 inches in length (strips of cardboard so eut will answer nicely if the former material is not at hand). 'J'wo of. these pieces or strips slould be bent to fit nver the ent of the finger in loop or horseshoe form, each loop being placed at right angles or crossing the stlier. flut sirle down, so that there is an anterior and a posterior, as well as two Jateral bars (four in all), extending lownward nenty to the second phalangenl joint, or lower. if this point js involved in the injury. $A$ strip of athesive plaster about $1 / 2$ incle wide is now bound firmly aroumd (it: may be split between the bars if momber tencts to swell much without impaiment of anchornge) Ho finger covering the distal ends of hars to the same depth, or it may lop over the distal ends on the tissue of the finger; the cage or guard will then be securely lied in a firm position.

A turn or two of gaume, to be first applied when strips are bent, will protect skin of finger from elges or ends of tin and prevent lnceration, or the edges may be boumd or rolled in alliesive plaster for the sime purpose. $\Lambda$ spene of from $1 / x$ to $1 / 4$ inch may be left brotween the ond of the finger and the inside of the guald through which the wound may be dressed from time to time.

The whole contrivance may then be (loser with turns of a handage or may be left, if desired, with strips of metal exposed

\section{ACETONURIA AND THE RETATION OF ACEYONE T'O “ACID INTOXICATION" *}

\author{
B. W. IIIAMY, M.J). \\ lathologlst [or l[opu 110 opltal \\ FORT WAYNE, INI).
}

The purpose of this paper is to report progress on some investigations regraling the nature of acetone and of its relative importance in the symptom-comples known as "acid intoxication." The present conception of this condition is that the toxemia is due to the acid qualities of the aretone bonlies, and that the acids, mamely, diacetic and beta-oxybutyrie acids, although not in themselves toxic, produce a condition of toxemin by miting with the dixed alkalies of the blood. 'The blood no longer being able to extract the poisonous carbon dioxid, the subject succumbs to "internal suffocation" from its accumulation in the tissues, the arids being cxcreted as ammonia compounds, resulting in a larger excretion of ammonia and a conseguent diminution of uren.

Ewing reports a study of arid poitoning by injecting intravenously eiglith-normal to fourth-normal hydroaliloric acid into rabbits. He fomed that they could stand large quantities of acids slowly administered (one receiving 1,485 grm. in eleven ravs), drowsiness being the chief symptom, with no dyspmea and no fatty degenerations of the liver or lidners. He gives the following oljections ngainst the purely acid nature of diabetic coma: Munser and Strasser leported cases with acotone and diacetic acid but no oxybutyice acid; coma may improve while the urine is still neid; alkalies mny not reduce the urinary ammonia; miliary tubereulosis and erysipelas have been found to reluce the ambon dioxid of the blool. Jwing concludes that some process is responsible for both comm and acids. He is of the opinjon that none of the principles of the theory of acid intoxication have been proved, mamely, carbon-dioxid asphyxiation, deconerations of vital organs by withdrawal of alkalies and retuced alkalinity. He concludes that more fundmmental knowleige of the source, occurrence, elomistry and plivsiology of the nectone bodies is neeled before correct interpretation can be obtained. The appearance of these bodies in such a virioty of toxic and debilitating comditions demonstrntes that they must pliy an impostant part in the pathology of metaboliam. An attempt, therefore, to know more of their mature and to hecome more familiar with their properties is at lenst worth while.

From the experiments of Knone and others it seems to be definitely sottled that the acotome bodics are clerived principally by faulty oxidation of fat and fatty acials, althomeh they can be formed to some extent from proteikls. 'lihis nlonormal splitting of fonts can take place luring alonormal atabolism or during faulty digestive processes in the intestine. As proof of the latter contention ean be offered the following data: Geolmuyen noticed acetonuria after adding olive oil and butter to a normal diet. Neuberg and Blumentlial foumd that hulvice acid by mouth increased acetome output, while sulbutaneous injoction alid not, ascribing this to activity of intestinal barteria. Beer and Blun fer organic ncils to diabetics and found an neetone output in ench instance. Schwartz found that fatty diet increased acetone output in cliabetes but not in health. (ieelmuyden

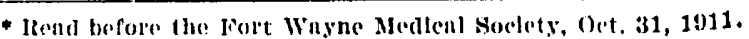

1. Ewlin: Arch. Int. Med $1008,11,330$ and 448 . 